\title{
Presenting a Green Human Resources Management Model in the Health Sector: A Grounded Theory
}

\author{
Leila Pezhman $^{1}$ iD, Mehraban Hadi Peykani2 ${ }^{*}$ (D), Mansoureh Pourmiri ${ }^{3}$ iD
}

\begin{abstract}
Introduction: Nowadays, green human resources management is one of the new approaches which is considered in all organizational and managerial fields. The health sector needs green human resources management to improve service quality more than other fields. Thus, the purpose of this research was to present a green human resources management model in the health sector.
\end{abstract}

Method: The research method was a qualitative grounded theory, and the participants were 28 health-related people in Isfahan in 1398. They were selected through the purposive sampling method, and in-depth semi-structured interviews were used for them. In order to analyze the data, open, axial, and selective codings were utilized.

Findings: Data analysis led to identifying the following items: 51 preliminary concepts, 16 central themes of structural context (software and hardware), attitude to health, health-oriented policy, social responsibility, cooperative culture, for-profit actors, managerial view of health, materialistic and meta-materialistic requirements, lifelong learning, competition opening, investment, health-oriented associations, employee empowerment, crises management, and the formation of health-oriented governance which formed the central theme of the research, i.e. "Green Human Resources Development as Sustainable Health Development". Moreover, in order to validate the findings, the analysis process was rereviewed and the opinions of five experts outside the research were used. Finally, all the main themes were incorporated into the paradigm model of Strauss and Corbin.

Conclusion: Given the views of the experts, it can be concluded that using green human resources management is implementable in the health sector. In addition, serious attention must be paid to its different aspects such as employee empowerment, hardware and software platforms, various investments, and specialized personnel.

Keywords: health; hospitals; human resources management; green resources; grounded theory

$\bullet$ Received: 03/Dec/2019 •Modified: 23/Feb/2020 •Accepted: 18/March/2020

1. Ph.D. Student in Management, Islamic Azad University, Khorasgan Branch, Isfahan, Iran, 1.pezhman@gmail.com

r. Assistant Professor, Management Department, Islamic Azad University, Khorasgan Branch, Isfahan, Iran; Corresponding author, mehraban.h.peykani98@gmail.com

r. Assistant Professor, Management Department, Islamic Azad University, Khorasgan Branch, Isfahan, Iran, poumiri90@gmail.com 


\section{ار ائه الخَوى مديريت منابع انسانى سبز در بخشى سلامت: ارائه يك نظريه مبنايى}

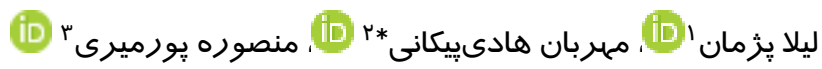

קكيده

مقدمه: امروزه مديريت منابع انسـانى سبز از رويكردهاى جديدى است كه در تمام حوزههاى سازمانى و مديريتى به آن توجه

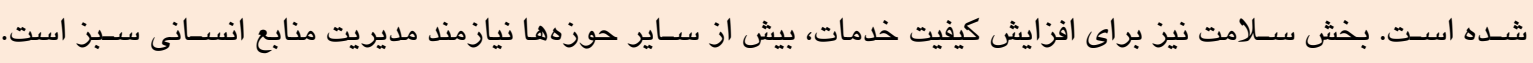

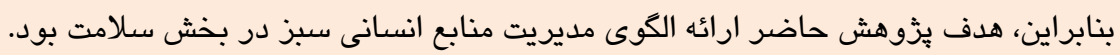

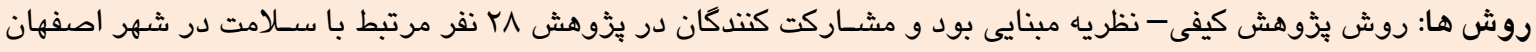

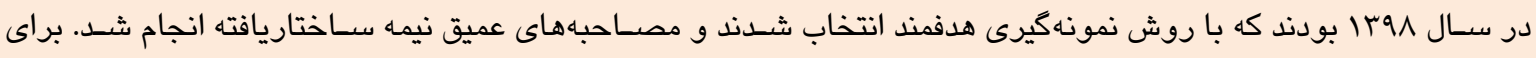

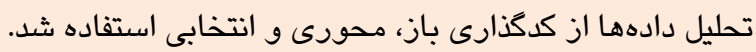

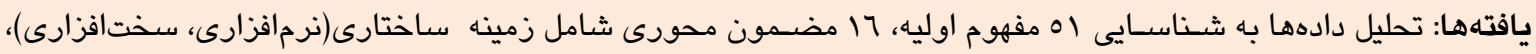

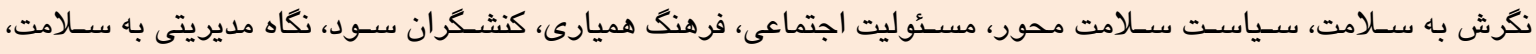

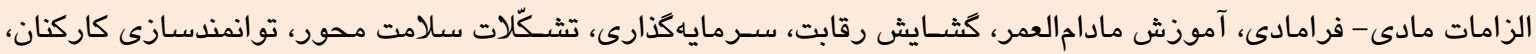

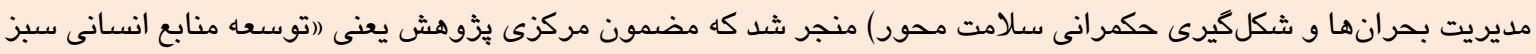

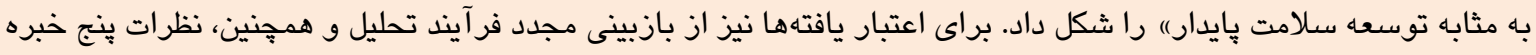
خارج از بذوهش استفاده شد. سرانجام، تمام مضامين اصلى در قالب مدل يارادايمى اشتراوس و كوربين قرار داده شدند.

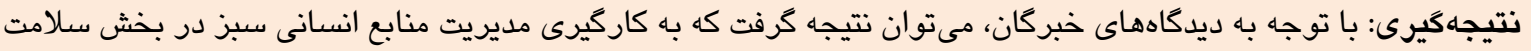

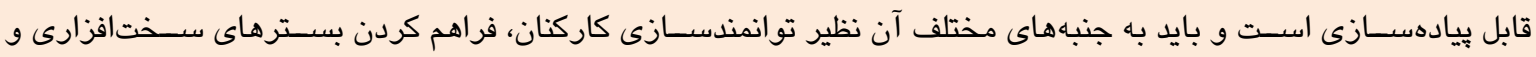
نرمافزارى، سرمايهكذارى مختلف و نيروهاى متخصص توجه جدى كرئ كرد.

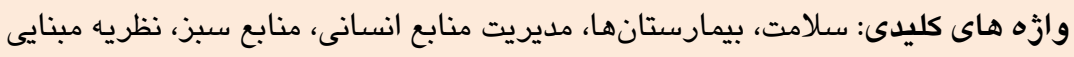

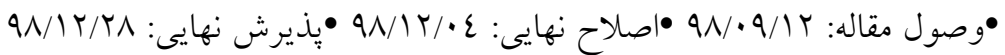

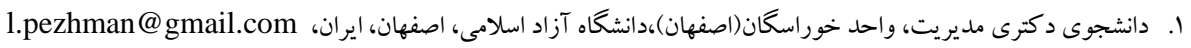

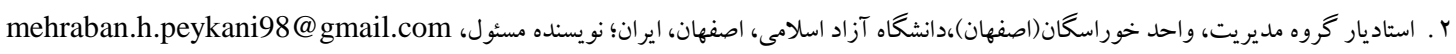

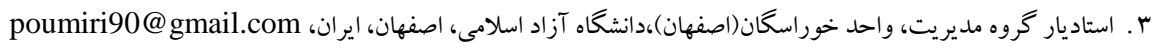


ملاحظات بسيارى را ماند كاهش آلودگىها و كنترل آن و افزايش بهرهورى به جاى مصرف فزاينده غير ضرورى در عملكرد زيست محيطى و مديريت زيست محيطى خود لحاظ نمايند. [V] اين ملاحظات در دل توسعه بايدار مورد توجه حاكمان و دولتمردان قرار گرفته تا در سايه ارزشهاى سبز اجتماعى، سازمان سبز را خلق نمايند. [^] هدف مديريت منابع انسانى سبز، به كاربردن سياستهايى براى بهبود كار كنان و پيايدارى زيست محيطى، استخدام، گزينث، آموزش وارزيابى عملكرد و پِاداش آنان است. [9] بيشتر تحقيقات مديريت منابع انسانى در صنايع و ديخر سازمانها بوده و بخش سلامت به عنوان مهمترين بخش زيربنايى هر جامعه هنوز به فراخور اهميت آن مورد يزوهش قرار نخر فته است. تو كلى و همكاران در يُروهشى نشان دادند نخهارى، جبران خدمات، مديريت عملكرد و توسعه منابع انسانى و رابطه بين اين نظامها با مديريت منابع انسانى سبز معنادار است. [•l] رجبيور در يُزوهشى نشان داد آموزش هاى زيست محيطى بايد جنان از سطح كمى و كيفى خوبى برخوردار باشند كه هر يكك از كار كنان، شناخت لازم را از شرايط اجتماعى، فرهنگى و زيست محيطى به دست

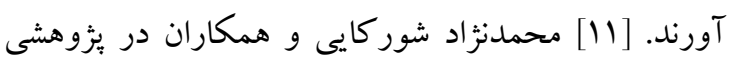
نتيجه گَرفتند اجراى موفقيت آميز برنامههاى مديريت منابع انسانى سبز، يُامدهاى مثبى را در لائ فردى، سازمانى و سطح جامعه به دنبال دارد. [YI فياضى در يُزوهشى نتيجه كرفت اجراى مؤثر آموزشهاى سبز نياز به فرهنك سازى و ايجاد زير ساختها و بسترهاى لازم دارد. [با] ادنان در يزوهشى در بيمارستانها و سازمانهاى بهداشتى و درمانى اردن نتيجه گرفت كه مديريت بيمارستانها بايد براى جذب و حفظ كارمندان با استعداد سبز، نظام ياداش مناسبى طراحى كنند زيرا اين استراتزى در نهايت افزايش آكاهى و تعهد

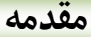

بخش سلامت هر جامعه مهم ترين بخش آن است كه بدون آن يك جامعه نمى تواند مدت زمان زيادى بايدارى خود را حفظ كند. [ [1] در جند دهأ اخير با شتاب تغييرات و صنعتى شدن، حوزه سلامت نيز با تهديداتى مواجه شده و در نتيجه فعاليتهاى بشر، كرة زمين متحمل صدمات جبر ان نايذيرى شده است. [r] آمارهاى سازمان ملل نشان مىدهند در قرن I Y مشكلات زيست محيطى مانند افزايش دما، افزايش دى اكسيدكربن، افزايش تخريب لاية ازن و افزايش زبالههاى شيميايى رو به افزايش بوده كه اهميت بخش سلامت و به كار گيرى مديريت آن را بيش از بيش جدى كرده است. [r] بخش سلامت حوزه گسترداى را شامل مىشود. بيمارستانها با توليد يسماندهاى خطرناك و آلودگى آب و هوا تأثيرات بدى برمحيط زيست و انسان بر جاى مى گذارند. [F] نظام سلامت وظيفه دارد بيامدهاى زيست محيطى را كاهش دهد تا بيامدهاى آن بر سلامتى انسان نيز كاهش يابد. [0] اين موضوعات اخيرا باعث ايجاد رويكرد جديد مديريت منابع انسانى سبز در تمام سازمانها به ويزٔه بخش سلامت شده است. مديريت منابع انسانى سبز مسئول ايجاد آكاهى، اطلاع رسانى و تعامل ميان كار كنان سازمان در خصوص عوامل محيطى است كه با خط مشىهاى سبز موجبات ايجاد مسئوليت اجتماعى در بين آنها شده تا به وظايف و تعهداتشان در قبال محيط عمل نمايند. [9] رويكرد مديريت سبز بر آمده از توجه به توسعه بايدار

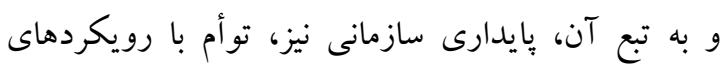
اجتماعى و انخيزههاى اقتصادى، سلامت و ايمنى جامعه، كاركنان و نيز نشر تصوير عمومى مطلوب سازمان در افق زمانى بلندمدت است. به همين خاطر سازمانها بايد براى تحقق ايدئولوزى سبز و باور عمومى به ارزشهاى سبز، 
مصاحبه با آنها صورت گرفت. براى تحليل دادهها از نظريه مبنايى استفاده شد كه به طور روز افزونى در حوزههاى مختلف به ويزٔه بخش سلامت توسط محققين براى مطالعه موضوعات مختلف استفاده مىشود. [19] در نظريه مبنايى سه مرحله كدگذارى وجود دارد. كد كذارى باز مربوط به مقايسه و خرد كردن دادههاست كه به مفهوميردازى و مقوله يردازى مى انجامد. در كد گذارى محورى تقليل مفاهيم صورت مى گيرد تا مضامين اصلى و انتزاعىتر شكل گيرند.

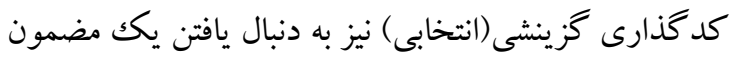

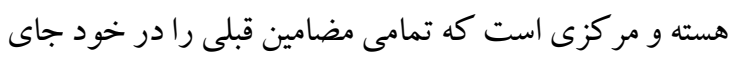
دهد. [•r] براى اعتبار يافتها نيز ابتدا تمامى فرايند سه كانه

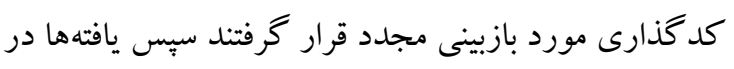

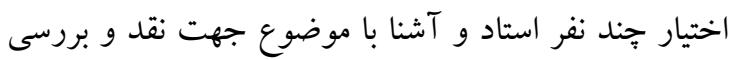

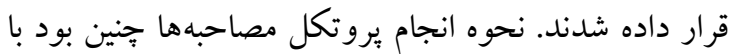
حضور در محيط بثوهش و ضمن تشريح موضوع و هدف

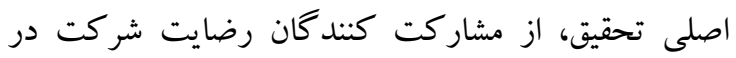

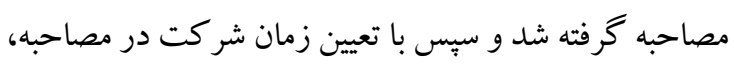

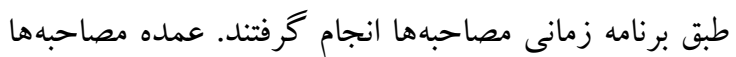
در محيط بيزوهش يعنى بيمارستانها و برخى نيز در فضاى

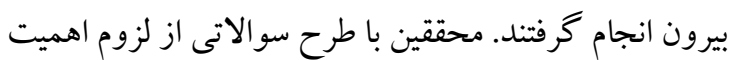

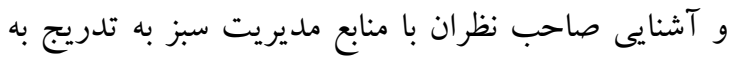
وييوند بخش سلامت و منابع سبز حركت كردند. زمان انجام

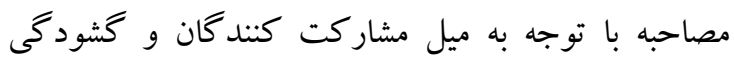
ياسخها به طور ميانگين •ه دقيقه بودند. تمامى اظهارات مئه مشار كت كنند كان يادداشت و بلافاصله تحليل شد. البته براى رعايت جوانب اخلاقى ييش از شروع مصاحبه رضايت مشار كت كنند كان براى ضبط متن مصاحبهها صورت گرفت كه در برخى موارد ميلى در ضبط مصاحبهها ديده نشد به همين دليل براى اطمينان خاطر به مشاركت كننده طبق ميل ايشان عمل شد. بعد از انجام هر مصاحبه تمام نكات و مفاهيم مهم و مرتبط موضوع مشخص شد و بر اساس كد كذارى باز تمامى جملات و كلمات تحليل شدند. در اين مرحله حدود

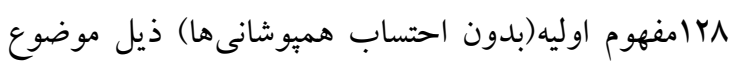

كار كنان نسبت به شغل خويش رابه همريت انهاه دارد. [IF] هلاوى و زراكت در يزوهشى نتيجه گرفتند افزايش نكر انىها نسبت به محيط زيست محسوس است. بازيافت و استفاده مجدد منابع براى جلو گيرى از برنامه سوء استفاده از طبيعت يكى از اقداماتى است كه جشمانداز سبز را نشان مىدهد. [10] ميلر و همكاران در يزوهشى تحت عنوان منابع انسانى سبز نتيجه كرفتند انجام اقدامات مديريت منابع انسانى سبز در حوزههاى باداش و ارزيابى عملكرد در سازمانها به ايجاد تعهد سبز در كار كنان منجر مىشود. [19] يانك و يوسف در يزوهشى نتيجه گرفتند كه موقعيت يابى استراتزيكك رابطه معنادارى با اقدامات مديريت منابع انسانى سبز دارند. قانون برنامه بنجم توسعه كليه دستگاههاى اجرايى و خدماتى را موظف به اجراى برنامههاى مديريت سبز نموده است. [11] از سوى ديخر، بى توجهى به بخش سلامت و عدم توجه به توانمندسازى كاركنان باعث تحليل انرزى و يكنواختى شغلى آنان مىشود كه اين مىتواند باعث فرسودگى شغلى و بى انخيز گى شود. بنابراين اين ضرورت ستى

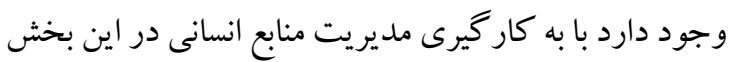
شاهد خدمات بهتر كاركنان و مانع هدر دادن سرمايههاى كشور بود. با عنايت به مطالب ذكر شده هدف اصلى يثوهش حاضر طراحى مدل مديريت منابع انسانى سبز در بخش

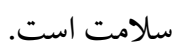

\section{روشها}

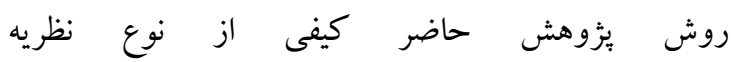

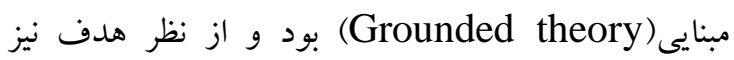

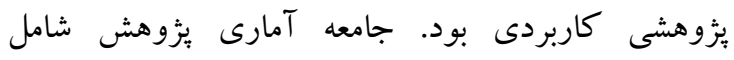
كارشناسان و خبر گان مديريت منابع انسانى دانشگاه علوم بردئ

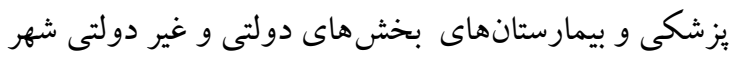

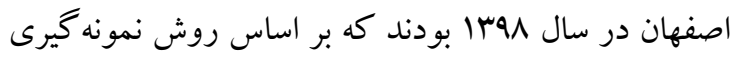

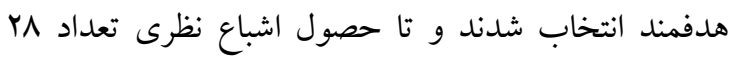


اينكه نوآورى /يشان به خاطر قوانين رفت و بركشتى دجار جالش و فراموشى شود "(مصاحبه شونده كد · ). "مديريت سبر استراتثى بين بخشى هست با يل تمام سازمانها از محيط زيست تا بهد/شت و دانشكاه يك تيم بشوند و به سوى طراحى مدل اصلاح بِماندها حركت كنند "(مصاحبه شونده

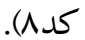

از ديدكاه خبر گان، سه مضمون محورى (امسئوليت اجتماعى")، (فرهنگك هميارى") و (اكنشخران سود) در قالب شرايط زمينهاى شناسايى شدند. برخى از اظهارات مهم

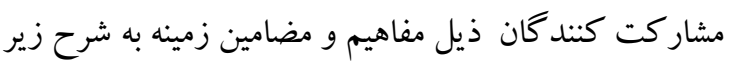

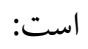
"ما مىتوانيم در بخش سلامت با بازيافت بِماندهاى بيمارستانها خدمت بزركى به محيط زيست(كه در واقع سود آن مال خود ما هست) بكنيم "(مصاحبه شونده كدץו). "الان ما بايد بر روى كارهاى كروهى تمركز

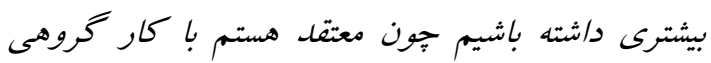
بسيارى /ز مشكلات مديريت منابع انسانى سبر حل خواهند شلد"(مصاحبه شونده كد (1)).
شكل گرفت كه با حذف موارد تكرارى و تعديل موارد ديخر در نهايت اله مفهوم نهايى شناسايى شد. در مرحله كد گذارى محورى همه موارد كد گذارى باز در 19 مضمون محورى طبقهبندى شدند و سرانجام بر اساس مضامين محورى، هسته

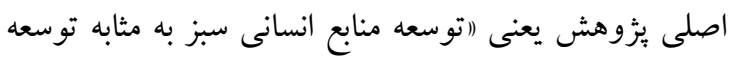

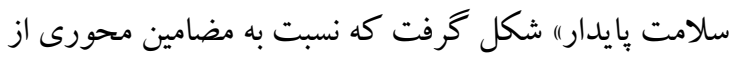

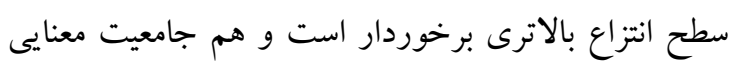

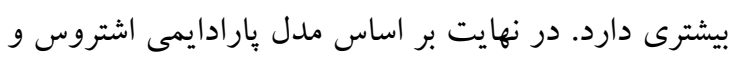
كوربين، تمام مضامين محورى در قالب الكو(شكل () ارائه

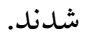

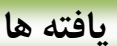

شرايط علّى در جهار مضمون اصلى مينه ساختارى(نرم|فزارى)، زمينه ساختارى(سخت(فزارى)، نغرش به سلامت و سياست سلامت محور قرار دارند. برخى از اظهارات مهم اطلاعرسانها در ذيل مضامين شناسايى شده قابل تأمل هستند: "دولت نقش كليدى در حما يت /ز سلامت مردم د/رد، الان سرما يه كذارى درشركت هاى بازيافتى و سبر محور در سطح جهان يكك /ولويت /ساسى هست "(مصاحبه شونده كد (). "قوانين ادارى اصلاح شوند كه شخص نوآور بتواند با سرعت كارهاى مقدماتى طرح خود را انجام دهد نه

جدول ا - شرايط علّى مديريت منابع انسانى سبز در بخش سلامت رت

\begin{tabular}{|c|c|c|}
\hline مفهوم & مضمون محورى & \\
\hline 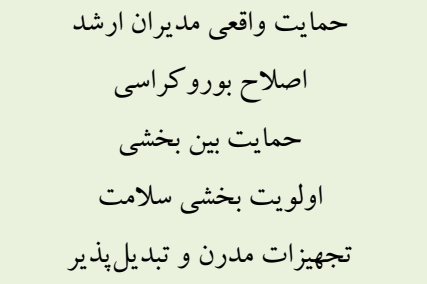 & زمينه ساختارى(نرم افزارى) & \\
\hline علم و دانش بين كسترده رشتهاى & زمينه ساختارى(فنى و دانشى) & شرايط علّى \\
\hline ميل به بهرهورى در سلامت & ن تكرش به سلامت & \\
\hline 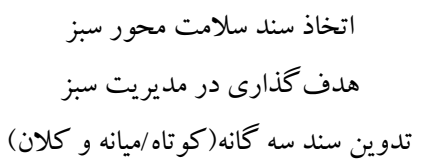 & سياست سلامت محور & \\
\hline
\end{tabular}


ارائه التَوى مديريت منابع انسانى...

جدول r- شرايط زمينهاى مديريت منابع انسانى سبز در بخش سلامت

\begin{tabular}{|c|c|c|}
\hline مفهوم & مضمون محورى & \\
\hline 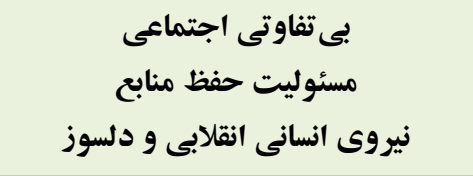 & مسئوليت اجتماعى & 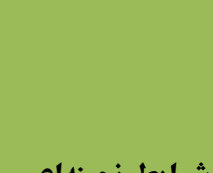 \\
\hline ترويج مشار كت تروهنى سازمانى و تيمى & فرهنك هميارى & \\
\hline وارد كنند كان محصولات سلامتى محور & كنشغران سود & \\
\hline
\end{tabular}

به اهميت حمايتهاى مادى و حتى فرامادى براى رونت ايدها در سلامت اشاره داشتند و معتقد بودند: "انخيزه و تشويقهاى مادى مىتواند زمينه تسريع در كارها را فراهم كند"(مصاحبه شونده كدم1). ذيل مضمون مهم و مداخله كر آموزشهاى مادام العمر نيز، مشاركت كنند گان زيادى معتقد بودند در حين كار و براى تقويت دانش و به اشتراك كذارى تجارب بايد دورههاى ضمن خدمت هدفمند به طور مدام وجود داشته باشد.
شرايط مداخله كر يا متعامل، شامل هر عامل است كه بر روى شكل گيرى يديده تأثير گذار باشد. سه مضمون محورى (انگًاه مديريتى به سلامت)، (الزامات مادى- فرامادى") و (آموزش مادام العمر") به عنوان شر ايط مداخله كر شناسايى شدند. برخى مشاركت كنتد كان معتقد بودند: "به كاركيرى حداكثر ظرفيت نيروهاى انسانى در سلامت نبايد يكك طرفه باشل يعنى نيرو بتواند / يلهها و برنامهاى خود را نيز به مقامات رارائه كنل و صرفًا از بالا نباشل "(مصاحبه شونده كد\&). مشاركت كنند كان ديخرى

جدول r- شرايط مداخله كر شكل دهنده مديريت منابع انسانى سبز در بخش سلامت

\begin{tabular}{|c|c|c|}
\hline مفهوم & مضمون محورى & \\
\hline برنامهامريزى از بالا به هايين & نكاه مديريتى به سلامت & \\
\hline 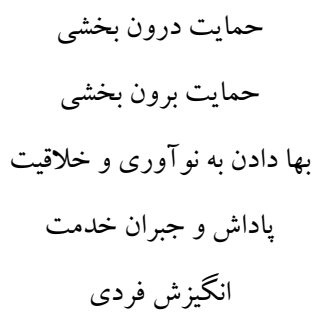 & الزامات مادى - فر امادى & شرايط مداخله \\
\hline تسورههاى ضمن خدمت & آموزش مادامالعمر & \\
\hline
\end{tabular}


كه در دل خود داراى جهار خرده مضمون است. نمونههايى از اين جهار خرده مضمون در ديدگاه مشاركت كنند عبارت بودنداز: "براى توسعه سبز بايد مركزى تخصصى در

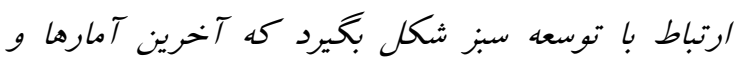
اطلاعات لازم در /ين بانكك به صورت به روز موجود

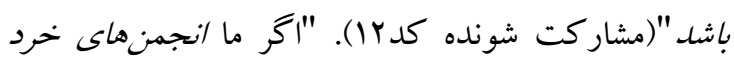
منطقهاى و حتى درون /ستانى داشته باشيم/ين مىتواند به تعامل بهتر موضوع توسعه سبر در بخش سلامت منجر شود" (مشار كت شونده كدها ).

در يزوهش حاضر جهار مضمون اصلى ("خشايش رقابت)، (سرمايه گذارى) و ("َشايش تشكّلات) از ديدكاه مشار كت كنند گان به عنوان راهبردها شناسايى شدند. عمده مشار كت كنندگان تأكيد داشتند رقابت بذيرى واكنشى معنادار و سازنده براى بازتوليد سلامت در جامعه است. براى مثال: "به نظرم اصل اساسى توسعه سبر رقابت بين همه بخشها و شركتها و /ستانها بايد باشد."(مصاحبه شونده كدV). بنابر اين يكى از راهبردهاى مهم توسعه انسانى سبز در بخش سلامت رقابت بين بخشهاى مختلف و ورود آنها به عرصه است. از مضامين ديخر، گشايش تشكلات سلامت محور بود

جدول ع- راهبردهاى بكار كيرى مديريت منابع انسانى سبز در بخش سلامت

\begin{tabular}{|c|c|c|}
\hline مفهوم & مضمون محورى & \\
\hline 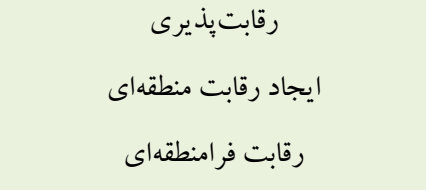 & كشايش رقابت & راهبردها \\
\hline سرمايه گذارى اقتصادى(كنش بهرهورى) سرايه گذارى فرهنگى (كنش نخرش) & سرمايه كذارى & \\
\hline
\end{tabular}

سازمان با بالاترين بهرهورى كار كنند" (مصاحبه شونده

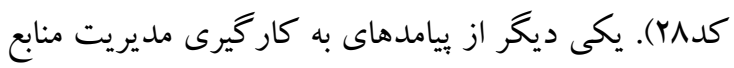
انسانى سبز در سلامت، مديريت بحرانهاست. 'الان

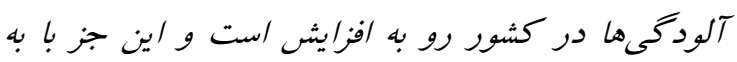
كاركيرى مديريت منابع انسانى سبر ميسر نمىشود"(مصاحبه

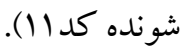

در يُزوهش حاضر (توانمندسازى كاركنان)، (امديريت بحرانها) و (شكل گيرى حكمرانى سلامت محور)" به عنوان ييامدهاى به كار گيرى مديريت منابع انسانى سبز در بخش

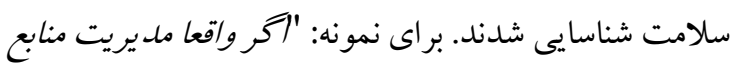
سبز در بخش سلامت خوب به كار گرفته بشود شكك نكنيد ما كاركنانى توانمند خواهيم د/شت كه قادر باشند براى 
ارائه الكَوى مديريت منابع انسانى....

جدوله- ييامدهاى حاصل از مديريت منابع انسانى سبز در بخش سلامت

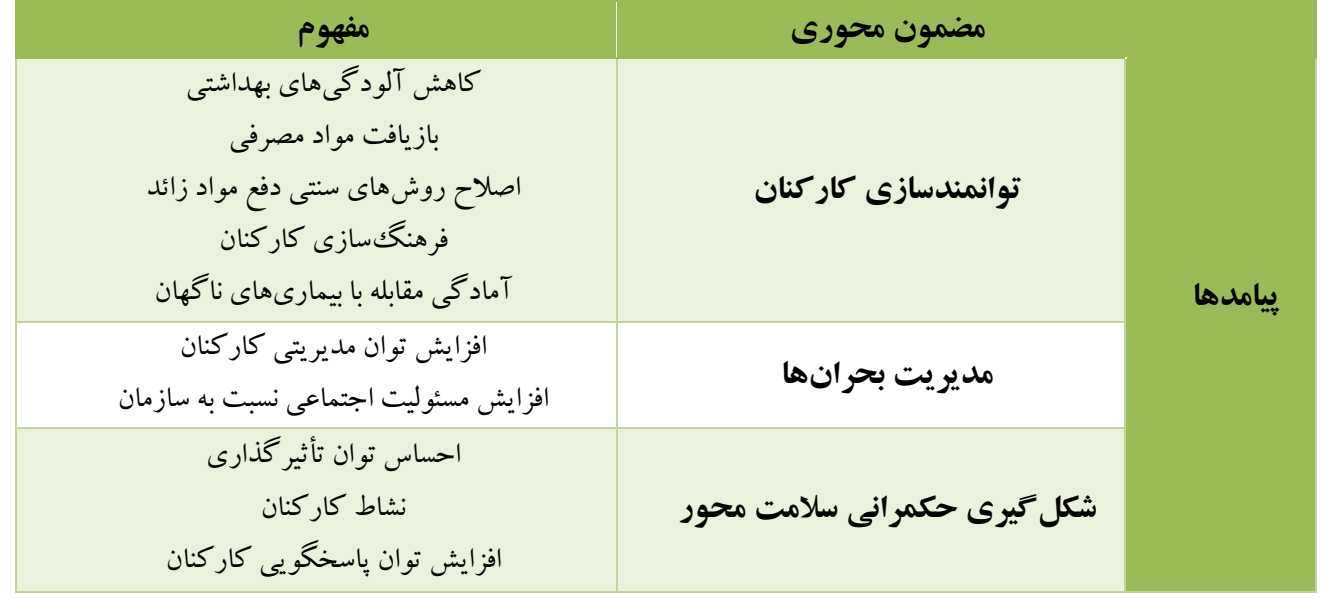

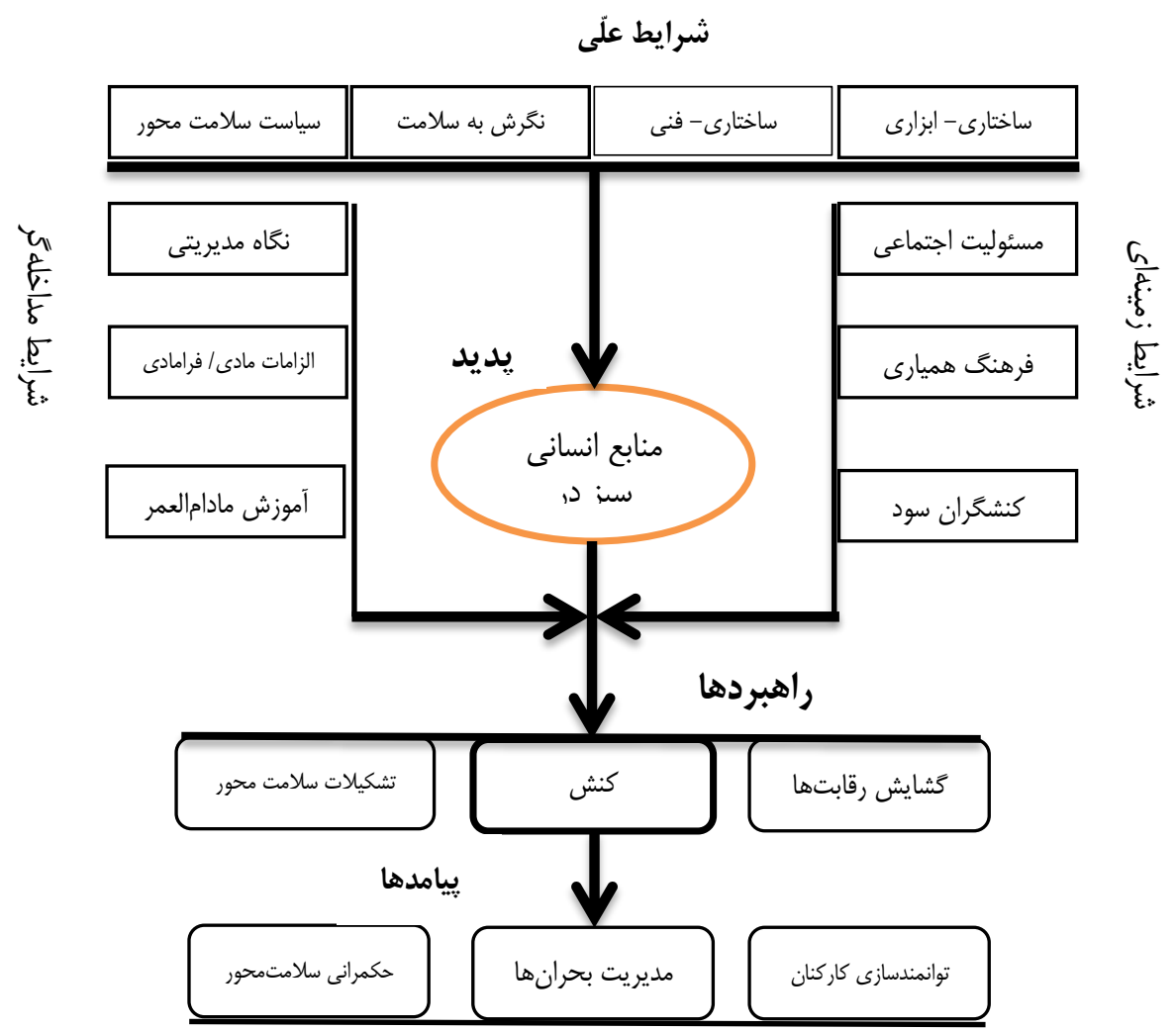

شكل ا. مدل پارادايمى اشتراوس و كوربين(شرايط على، زمينهاى، مداخله ترو راهبردها و ييامدها)

سبز شامل "(زمينه ساختارى - نرمافزارى)، (ازمينه ساختارى -

سخت سزارى)، (انكرش به سلامت) و (تدوين سياست سلامت

محور") هستند. اين يافته با نتايج يثوهشهايى مانند تو كلى و

\section{بحث}

همكاران(IMqV) كه نتيجه كرفتند نكرش به سلامت عنصر

هدف يزٔوهش حاضر ارائه الكوى مديريت منابع انسانى سبز در حوزه سلامت بود. يافتها نشان دادند شرايط علّى دخيل

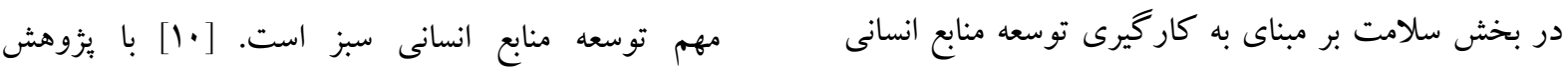


نسبت به مضامين بيشين خود برخوردار است و همجِنين مى تواند بار مفهومى آنها را در خود داشته باشد. شرايط علّى لي لي مىتواند مستقم بر روى بديده اصلى يعنى توسعه منابع انسانى سبز در بخش سلامت اثر بخذارد و ايجاد كننده آن باشد. از طرفى شرايط مؤثر ديخر يعنى شرايط زمينهاى و مداخله نيز مى تواند بر روى شكل گيرى بديده اثر خذار باشند. شرايط زمينهاى و مداخله گر مىتواند در مسير پيديده نقش تسهيل كننده و مانع ايفا كنند. يِيامدها كه در واقع حاصل نهايى راهبردها هستند مى توانند آثار و نتايج منفى، مثبت و حتى رفتارهاى حنثى باشند. اين روابط در كل نشان دهنده شرايط متنوع و اثر گذار در ايجاد يديده هستند. يكى از محدوديت يثزوهش حاضر جالش يافتن زمان براى مصاحبه با خبر كان بود كه اين امر براى محقق سختىهايى ايجاد كرد. محدوديت ديخر بزوهش اين است كه تحقيق حاضر با توجه به ماهيت كيفى خود قصد تعميميذيرى ندارد اما يافتهاى آن قابل تأمل هستند. بر اساس نتايج بيشنهاد مىشود: ا-براى كاركنان كار كاههايى با تأكيد بر آخرين روش هاى مرتبط با سلامت و زيست محيطى به طور مستمر اجرا شود و كاركنان به تبادل نظر ببردازند. r-با توجه تأكيد

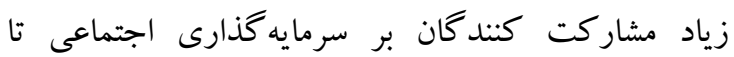
اقتصادى، ييشنهاد مى شود با استفاده از فضاى رسانهاى بسترى ايجاد شود كه همه افراد بهويزه كاركنان مرتبط با سلامت نسبت به اهميت و نقش منابع انسانى سبز در سلامت حساستر شوند. r- در هر درمانگاه و يا جند مجتمع، يك تيم محقق قرار داده شود تا به طور مدام امور مربوط به منابع انسانى سبز رصد و مطالعه شود و در واقع تيمى متشكل از نخبكان با تشريكك مساعى با تأكيد بر تحقيق و ارائه نتايج شكل بخيرد.

\section{ملاحظات اخلاقي}

ملاحظات اخلاقى به مشاركت كنندگان اطمينان خاطر داده شد كه دادههاى يثزوهش و هويت افر اد محرمانه بوده و در اختيار ديخران قرار
رجب يور(4) (1) كه ساختار تشكيلاتى و تخصيص منابع را يكى از عناصر كليدى نظام مديريتى حفظ محيط زيست ارزيابى كردند. [11] و با يُوهش يانگك و يوسف كه نقش زيرساختها را در توسعه منابع انسانى سبز مهم دانستند. [IV]

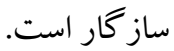
يافته ديخر يثزوش حاضر مسئوليت اجتماعى، فرهنگ هميارى و كنشخران سود بود كه به عنوان شرايط زمينهاى شناسايى شدند. اين يافته با نتيجه تحقيق تو كلى و همكاران مبنى بر نقش تعهد كارى و فرهنگ سازمانى كاركنان در توسعه منابع انسانى سبز سازگار است. [•[1] فياضى نيز در يزٔوهش خود نتيجه كرفت اجراى مؤثر آموزشهاى سبز نياز به فرهنگ سازى و مسئوليت اجتماعى دارد كه با نتيجه

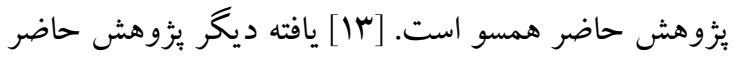
نكاه مديريتى به سلامت، الزامات مادى - فرامادى و آموزش مادامالعمر بود كه به عنوان شرايط مداخلهاى شناسايى شد. اين يافته نتايج تحقيقاتى مانند تو كلى و همكاران؛ رجب بور؛ فياضى و ادنان كه بر بعد آموزش و توجه به بسترهاى مادى تا

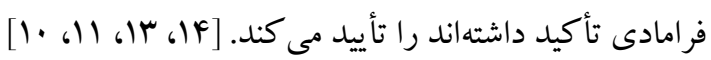
يافته ديخر ويزوهش حاضر ايجاد فرصتهاى رقابتى، سرمايه گذارىها و ايجاد تشكّلات سلامت محور بود. اين يافته با نتايج تحقيقاتى مانند محمدنزاد شور كايى و همكاران؛ هلاوى و زراكت و ميلر و همكاران ساز كار است. [19، ها، IY] يافته ديكر توانمندسازى و مديريت بحر انها و حكمرانى سلامت محور بود. اين يافته كه به عنوان بيامدها شناسايى شد نتايج يزوهشهاى محمدنزاد شوركايى و همكاران ؛ رجب يور و ادنان [|F-|F] را مورد تأييد قرار مىدهد. هسته مركزى يزوهش حاضر با استناد به مضامين محورى و مفاهيم اصلى را مى توان توسعه منابع انسانى سبز به مثابه توسعه سلامت يايدار ناميد. اين نظريه از سطح انتزاع بالاترى 
تضاد منافع: هيج گونه تعارض منافعى وجود ندارد.

تشكر و قدردانى: از تمام اساتيد و خبر گانى كه با بيانى

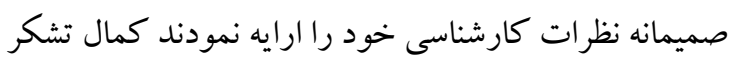

مىشود.

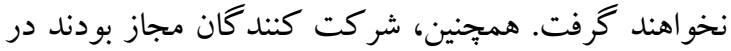
هر مرحله با اختيار خود مطالعه را تركك كنند.

حمايت مالى: اين يزوهش بدون حمايت مالى سازمان و

نهاد خاص بود و بخشى از رساله دكترى مديريت منابع انسانى

\section{References}

1. Boyce T, Brown C. Economic and social impacts and benefits of health systems. Denmark: WHO; 2019 Jan 08. Report No 5. available from: who.int/iris/handle/10665/329683.

2. Wagner M. Green Human Resource Benefits: Do they Matter as Determinants of Environmental Management System Implementation. Journal of Business Ethics. 2012; 14(3): 443-65.

3. UNEP. Global environment outlook: summery of policy makers. US: United nation environment program. 201920 Feb. 22. Report No: 5. available from:

https://www.unenvironment.org/resources/report/global-environment-outlook-5- ummarypolicymakers

4. Riley M. Human Resource Management for the Hospitality and Tourism Industries, D. Nickson, Butterworth Heinemann. United Kingdom: Oxford Press; 2008.

5. Hancock T. Greening Healtheare: An emerging international movement. Hospital Quarterly fall. 2001; 4(4):21-32.

6. Seyed Javadin S. R., Roshandel Arbatani T. Nobari A. Green Human Resource Management, an Investment and Sustainable Development Approach, Journal of Investment Knowledg. 2015; 5(20): 297-327. [In persian]

7. Sabet A, Azizi M. Assess the impact of human resource strategies in the creation and development of Green human resource management. Journal of New Research Approaches in Management and Accounting. 2020; 4(31):67-85.

8. Fernando $\mathrm{Y}$, Jabbour $\mathrm{C}, \mathrm{Wah}$ W.X. Pursuing green growth in technology firms through the connections between environmental innovation and sustainable business performance: does service capability matter? Resour. Conserv. Recycl. 2019; 2(1):141-154.

9. Karimi Zarchi M, Sadat Ahmadinejad S. Identifying and determining the priority of green human resource management measures using fuzzy topsis technique, new research approaches in management and accounting. 2017; 6(2):143-152. [In persian]

10. Tavakoli A, Hashemi A, Sabet A, Razeghi S. Providing a structural model of green human resource management based on human resource management systems, Human Resource Management Research. 2018; 10(1):77-104. [In persian]

11. Rajabpour I. The Impact of Human Resource Management on the Development of Environmental Management, Human Resource Management Research. 2017; 9(1): 51-74. [In persian] 
12. Mohammadnejad Shoorkai M, Seyed Javadin, S. R, Shah Hosseini, M. A, Haj Karimi A. A. Provide a framework for green human resource management, public administration. 2015; 8(4): 691-710. [In persian]

13. Fayazi M. Green Education Human Resources in the Oil Industry, Quarterly Journal of Educational Research in Law Enforcement Sciences. 2015; 3(3): 1-20. [In persian]

14. Adnan M. The impact of green human resource management on organizational environmental performance in Jordanian health service organizations. Management Science Letters. 2018; 8(3):1049-1058.

15. Halawi A.H, Zaraket W. Impact of Green Human Resource Management on Employee Behavior, Journal of Applied Business Research. 2018; 6(1):18-34.

16. Millar J, Chandana S, Müller C. Green human resource management: a comparative qualitative case study of a United States multinational corporation. The International Journal of Human Resource Management. 2016; 27(2):192-211.

17. Yong J. Y, Yusoff y. m. studying the influence of strategic human resource competencies on the adoption of green human resource management practices. Industrial and commercial training. 2016; 48(4): 416-422.

18. Document of the Fifth Five-Year Development Plan of the Islamic Republic of Iran (20112015).[In persian]

19. Murray-Davis B, Grenier L, Atkinson S. A, Mottola M. F, Wahoush O, Thabane L, et. al. Experiences regarding nutrition and exercise among women during early postpartum: a qualitative grounded theory study. BMC pregnancy and childbirth. 2019; 19(1): 368-75.

20. Bryant A. Grounded theory and grounded theorizing: Pragmatism in research practice. United Kingdom: Oxford University Press: 2017. 